\title{
The Role of Microorganisms in the Revegeta-
}

\section{tion of Strip-Mined Land in the Western United}

\section{States}

\section{A. M. CUNDELL}

Highlight: This paper discusses the role of microorganisms in the reclamation of spent shale wastes in western Colorado and the overburden from lignite strip-mining areas in North Dakota. Adverse conditions for plant growth such as low organic matter content, salinity, fine texture and a lack of nitrogen and phosphorus, and a slow rate of soil formation limit the revegetation of the mining wastes. Microbial processes are responsible for the accretion of soil organic matter, the fixation of nitrogen, and the modification of adverse soil properties with the spoil. Possible strategies to take advantage of microbial activities to encourage plant growth in strip-mined land are discussed. Fertilization, seeding, mulching, the inoculation of the rhizosphere of perennial grasses with free-living heterotrophic nitrogen-fixing bacteria, and the production of sulphuric acid by sulphur-oxidizing bacteria to lower the pH of the spoil are reviewed.

The surface mining of oil shale and lignite in Colorado, Utah, Wyoming, Montana, and the Dakotas to satisfy future energy needs in the United States poses a number of environmental problems. The most serious of these problems are the destruction of lands, wind erosion, and water pollution by sediment and leached salts.

Environmental restraints will insure surface mining procedures which will include overburden segregation to separate potential pollution-forming materials from topsoil to be used in revegetation, water control to prevent short duration discharge of large quantities of sediment and salts, regrading to restore the land relief and to prevent erosion, and revegetation to stabilize the reclaimed area allowing for future land-use (Anon. 1973; Weaver 1975).

Vegetative cover, especially grasses and small herbaceous plants, is required to stabilize strip-mined land after the economic product has been recovered. However, the adverse chemical and physical properties of spoil and a lack of water may discourage plant growth. The unavailability of seed of native grasses and the high cost of irrigation, fertilization, and mulching in the face of marginal success in some revegetation trials are sufficient reasons to reassess the problems of reclamation of mine spoils. The vegetation surrounding the reclamation areas will often represent climax plant communities or

The author was a Fellow in applied biology in the Division of Enginetering and Applied Physics. Harvard University, Cambridge. Massachusetts 12138. His present address is ARK Research. 55 Rome St., Furmingdale. N.Y. I 77.35

Manuscript received August 14, 1976 farm land managed for economic advantage and may lack the pioneering plant species necessary to colonize bare spoil. It should be emphasized that merely transplanting trees found late in a plant succession into strip-mined areas is often not adequate to establish stabilizing ground-cover, since plant succession is necessary for soil formation and homeostasis. However, considerable progress has been made in determining the most suitable surface-mine rehabilitation in western lands (Cook 1976) and, hopefully, new strategies will be developed from further research on land reclamation.

It is well known to biologists that soil microorganisms have an important role in soil formation and revegetation. Microorganisms are agents responsible for the physico-chemical changes to the mine spoils necessary for satisfactory plant growth. These changes include the accumulation of soil organic matter, increases in available plant nutrients especially nitrogen and phosphorus, improvements in soil texture, water-holding capacity and soil reaction.

In this review, the microbial processes involved in the revegetation of strip-mining areas in the Western States will be discussed, using the revegetation of spent oil shale wastes in western Colorado and the graded overburden arising from the strip-mining of lignite in western North Dakota as examples of reclamation problems.

\section{Characteristics of Spent Shale Wastes in Western Colorado}

The feasibility of shale oil production on a commercial scale from the Piceance Basin, west Colorado, has been investigated by an oil company consortium (Colony Development Corporation). The following procedure is used by the consortium to obtain shale oil: Crushed shale is preheated, mixed with hot ceramic balls in a rotating retort, and equilibrated at $900^{\circ} \mathrm{F}$ $\left(482^{\circ} \mathrm{C}\right)$, which is sufficient to cause thermal decomposition and vaporization of the kerogen, the organic constituents of the shale. The vapors are condensed and fractionated into gas, naphtha, gas oil, and a heavy residium. The balls are separated from the spent shale and recirculated to a ball heater. The spent shale wastes are then moistened to control dust and to obtain the necessary compactive properties for the stabilization of the spent shale piles. A minimum economic-sized shale oil plan will produce in excess of 50,000 tons $\left(50.8 \times 10^{\mathrm{h}} \mathrm{kilograms}\right)$ of processed shale per day [approximately 1 ton (1,016 kilograms) 
of high-grade shale rock will produce 45 gallons ( 170 liters) of shale oil]. The disposal of spent shale wastes poses a number of environmental problems including dust hazards, erosion of spent shale piles, pollution of surface water by sediment and leached salts, and the general destruction of scenic beauty. It is the intention of the operating company to spread spent shale wastes along canyon floors. Compaction, fertilization, and irrigation of the shale wastes may enable revegetation to be achieved and hence prevent an adverse environmental impact within the production area (Ward et al. 1971).

The spent shale wastes from Atlantic Richfield's TOSCO II process consists of a fine granular, dark residue which is claimed to be essentially hydrocarbon free (Kilburn 1973). Leaching tests show that there is a definite potential for a high concentration of $\mathrm{Na}^{+}, \mathrm{Ca}^{2+}$, and $\mathrm{SO}_{4}^{2-}$ ions in the runoff from spent oil shale residues (Ward et al. 1971). Schmehl and McCaslin (1973) investigated the ability of wheatgrass (Agropyron elongatum) and Russian wildrye (Elymus junceus) to grow in soil-amended shale in greenhouse trials. Chemical analyses of spent shale wastes showed that the material was highly saline, highly alkaline, lacking organic matter, and low in available phosphate and nitrogen. The growth of the two grasses in untreated shale was negligible. Furthermore, the addition of up to $50 \%$ soil failed to produce significant growth. However, when spent shale was reclaimed by leaching to remove excess salts, good growth of the grasses was obtained if both nitrogen and phosphorus fertilizers were applied to the spent shale (Schmehl and McCaslin 1973).

Soil development and leaching of salts from the spent shale are necessary for sustained plant growth. Abiotic processes, such as weathering, leaching, freezing and thawing, and wetting and drying, and biotic processes such as the capture of energy, accumulation of organic material by plants, and the decomposition of these plant residues by the developing population of soil microorganisms promote soil formation (Buol et al. 1973). The minerals found in the spent shale, namely dolomite, calcite, and illite, are relatively readily weathered. However, leaching of the wastes is slow because of low rainfall within the area.

Arid soils are characterized by low rainfall and high evaporation, low microbial populations, low organic matter content, and low carbon-nitrogen ratios. In semidesert regions, soil formation accompanies the colonization of the substratum of blue-green algae, lichens, and eventually grasses and shrubs. The decomposition of plant residues leads to the formation of humic material, which increases the cation-exchange waterholding capacities, and aggregation of the soil. Cationexchange capacity is important in the storage and release of important plant nutrients such as $\mathrm{NH}_{4}^{+}, \mathrm{K}^{+}, \mathrm{Mg}^{2+}$, etc., while soil aggregation is necessary to maintain aeration. Soil microorganisms are important in recycling plant nutrients. Background information on soil formation in materials such as spent shale wastes can be obtained from published studies on soil formation in sand dunes (Webley et al. 1952), Antarctic dry valleys (Boyd et al. 1966; Tedrow and Ugoliai 1966), spoil from glaciers (Crocker and Major 1955), and in West Virginia stripmine spoils (Wilson 1965).

\section{Characteristics of Typical Overburden Materials in Western North Dakota}

Lignite is mined when beds are greater than 5 feet $(1.525$ meters) thick, with overburden less than $120 \mathrm{ft}(36.6 \mathrm{~m})$ thick, and in blocks containing 5 million tons $\left(5.08 \times 10^{9} \mathrm{~kg}\right)$ or more. Estimated strippable reserves in North Dakota range from 4 to 7 billion tons ( 4 to $7 \times 10^{12} \mathrm{~kg}$ ) with the production of 6.3 million tons $\left(6.4 \times 10^{9} \mathrm{~kg}\right)$ in 1972 and over 300 acres $\left(1.2 \times 10^{6} \mathrm{~m}^{2}\right)$ of land stripped per year. A projected 45 million tons $\left(4.6 \times 10^{10}\right.$ $\mathrm{kg})$ of lignite may be produced with over 3,000 acres $\left(12 \times 10^{7}\right.$ $\mathrm{m}^{2}$ ), disturbed per year by 1990 in North Dakota (Sandoval et al. 1975). The low sulphur content of the coal, availability of water from the Garrison Diversion, and the demand for electrical power generation make the development of this energy resource attractive.

Field and laboratory studies have shown that a variety of stripmine spoils derived from the mining of lignite are not good substrates for the growth of perennial grasses. Adverse overburden properties include fine texture, low organic matter content, moderate salinity, high sodic content, and a lack of plant nutrients, namely, nitrogen and phosphorus (Omodt et al. 1975; Sandoval et al. 1973).

The present reclamation law in North Dakota requires that two feet of suitable topsoil cover the leveled spoil, having about $2 \%$ organic matter content, not being saline (conductivity $\geq 2$ mmhos $/ \mathrm{cm}$ ), exchangeable sodium lower than $5 \%$, and free lime lower than $10 \%$; hence, it will be necessary to practice overburden segregation during stripping operations (Grimm and Hill 1974).

Chestnut and reddish-chestnut soils characteristic of western North Dakota and eastern Montana have a decreasing organic matter content with decreasing rainfall closer to the Rocky Mountains. As the rainfall diminishes the soil profile is less pronounced, and a zone of calcium carbonate accumulation can be found nearer the surface in textured soil derived from glacial till and loess (Buckman and Brady 1960; Omodt et al. 1975). A high percentage of free lime in overburden or reconstituted topsoil may weaken the soil structure because of the high clay content, induce deficiencies of available iron, manganese, copper, or zinc, and decrease the phosphate availability due to the formation of insoluble calcium phosphate (Buckman and Brady 1960).

The lignite areas are primarily used for dryland cropping and range livestock raising and are an agricultural resource needed to produce food. The reclamation of the spoils is complicated by their high clay and sodium content. The presence of sodium montmorillonite in the spoil leads to serious physical defects, and it is likely to be too difficult to till, exhibiting high plasticity, poor water infiltration, high swelling capacity, and will shrink on drying causing severe cracking. Recent investigations by Sandoval and his co-workers (Sandoval et al. 1973) show that chemical amendment with gypsum and sulphur will increase calcium availability and hence alleviate the high sodic conditions while phosphorus treatment is necessary to support the growth of barley.

Spent shale wastes and strip-mine spoil both have physical and chemical properties that restrict their revegetation. These properties are summarized in Table 1 .

\section{Role of Microorganisms in Soil Formation}

In this discussion of the role of microorganisms in the reclamation of mine spoil, emphasis will be placed on: (a) the accumulation of organic matter, (b) operation of the nitrogen cycle, and (c) $\mathrm{pH}$ adjustment by the activities of sulphuroxidizing bacteria within the spoil.

Studies of so-called chronosequences, the effect of time as a soil-forming factor, suggest that the following broad trends 
Table 1. Adverse properties of spent shale wastes and spoil material. ${ }^{1}$

\begin{tabular}{|c|c|c|c|c|c|c|c|c|c|}
\hline \multirow[b]{2}{*}{ Material } & \multirow[b]{2}{*}{$\mathrm{pH}$} & \multirow{2}{*}{$\begin{array}{l}\text { Conductivity } \\
(\mathrm{mmhos} / \mathrm{cm})\end{array}$} & \multirow{2}{*}{$\begin{array}{c}\mathrm{CaCO}_{3} \\
\text { equivalent } \\
(\%)\end{array}$} & \multicolumn{3}{|c|}{ Cationic concentration } & \multirow{2}{*}{$\begin{array}{c}\text { Sodium } \\
\text { adsorption } \\
\text { ratio (ISAR) }\end{array}$} & \multirow{2}{*}{\multicolumn{2}{|c|}{$\begin{array}{c}\text { Saturation } \\
(\%)\end{array}$}} \\
\hline & & & & $\mathrm{Na}^{+}$ & $\mathrm{Ca}^{2+}$ & $\mathrm{Mg}^{2+}$ & & & \\
\hline $\begin{array}{l}\text { Spent shale waste } \\
\text { (TOSCO II) }\end{array}$ & 8.9 & 26.0 & 31 & 196 & 18.5 & 78.5 & 28.2 & 20.4 & (Field moisture capacity) \\
\hline $\begin{array}{l}\text { Overburden } \\
\text { (Zap. N.D.) }\end{array}$ & 8.8 & 2.0 & 10 & 19 & $<1$ & $<1$ & 48.0 & 160 & (Saturation capacity) \\
\hline $\begin{array}{l}\text { Topsoil } \\
\text { (Zap. N.D.) }\end{array}$ & 7.3 & $<1$ & 1 & 1 & 5 & 3 & $<1$ & 36 & (Saturation capacity) \\
\hline
\end{tabular}

'From Sandoval et al. 1973 and Ward et al. 1971.

occur over extended periods of time during soil formation (Stevens and Walker 1970). Rapid initial changes in mineral soils are due to the accretion of organic matter. With time, depth-gradients of a number of soil parameters are established, for example: $\mathrm{pH}$, cation exchange capacity, $\mathrm{CaCO}_{3}$ content, organic matter, total carbon and nitrogen, and soil aggregation. It is well recognized that soil development is a direct consequence of the advent, growth, and areal distribution of vegetation. The nature of the plants colonizing bare substrata will be determined by external factors such as the neighboring vegetation and ecological factors including competition for light, nutrients, and soil moisture. Early in the vegetation succession, nitrogen-fixing plants are present, and they are replaced by other plants that utilize the accumulated nitrogen (Stevens and Walkcr 1970). For example, the recolonization of spoil banks in the Mesabi Iron Range, Minnesota, was described by Leisman (1957). The pioneer species are transported onto the spoil as disseminules by the wind, birds, or mammals and include herbaceous weeds, sod-forming Kentucky bluegrass (Poa pratensis), and nitrogen-fixing clover (Trifolium repens). Within 13 years, aspen (Populus tremuloides) and balsam poplar (Populus balsamifera) had become established. Soil analyses showed that from 2 to 52 years the $\mathrm{pH}$ decreased from 7.5 to 5.9 , the percentage moisture equivalence increased from 10 to $22 \%$, percentage organic carbon increased from 0.08 to $1.26 \%$, total nitrogen increased from 0.005 to $0.098 \%$, and the carbon-nitrogen ratio decreased from 16 to 12 . Zonation of the soil was apparent after 13 years and the $A_{0}$ and $A$ horizons developed slowly with their depths at 0.5 and 1.75 inches respectively after 52 years.

During the plant succession from bare spoil to a climax plant community, soil formation will occur as a net increase in soil organic matter and minerals. There will be an annual increase due to weathering, accretion of humus, and accumulation of plant nutrients that will result in a gradual increase in soil fertility (Witkamp 1971). Populations of soil microorganisms will reflect the plant succession. Examples include the microflora of bare substrata such as rocks, the activities of microorganisms within the rhizosphere, and the physiological properties of microorganisms in different stages of the succession.

In semiarid regions, mining spoil like spent shale wastes, which are dark in color, contain little or no carbon, and have a low moisture-holding capacity, may be colonized by blue-green algae and lichens (Fletcher and Martin 1948; Rychert and Skujins 1975). The accumulation of organic material due to the photosynthetic activity of the blue-green algae-lichen crust and their ability to fix atmospheric nitrogen stimulates the growth of microorganisms, and the higher nitrogen status will encourage the appearance of annual weeds and perennial grasses. The resulting humic material increases the cation-exchange and water-holding capacity of the spoil. A spectrophotofluorometric method for studying algae in soil has recently been developed (Sharabi and Pramer 1973) that could be applied to counting soil algae and lead to additional investigations of their role in soil formation.

The number and type of bacteria inhabiting a soil depend on its soil type, degree of cultivation, and plant cover. A number of gross generalizations are possible about this relationship, the most well known being that the number of bacteria within a mineral soil is a reflection of its organic matter content; however, moisture, oxygen availability, inorganic nutrients, and temperature will all markedly affect the microbial population within a soil (Alexander 1969).

The microflora of bare substrata such as rocks appears to be characterized by the predominance of mycobacteria capable of fixing atmospheric nitrogen and mineralizing rocks by chelation with metallo-organic complexes secreted by the microorganisms (Sushkina 1970). The amount and degree of decay of plant material markedly influences the types of microorganisms present in soil. In general, primitive soils with low organic matter have a microflora characterized by mycobacteria. The early decomposition of plant material is mediated by nonsporing bacteria such as Pseudomonas spp., while the extreme decomposition of plant material favors the reproduction of Bacillus spp. and actinomycetes (Mishustin 1975).

Dominant populations of soil microorganisms in different soils were described by Gray and his co-workers (Goodfellow et al. 1968). Generally, corynebacteria dominated cultivated soils, with gram-negative rods like pseudomononads being more prominent in the rhizosphere of plants. An increase in streptomycetes in dry alkaline soil was noted. The root zone of all plants supports a large and active microflora. The rhizosphere of grasses is particularly important in the stabilization of mining spoil where soil properties are unfavorable in the surrounding spoil for microbial growth.

A review of the work of Soviet soil microbiologists by Mishustin (1975) suggested that a generalization about the major groups of microorganisms in different soil types may be possible. In Russian soils similar to those soils found in western North Dakota (Chestnut) and western Colorado (Brown and Sierozems), he reported 3.5 to $4.5 \times 10^{6}$ microorganisms per gram of soil using plating techniques. Proportions of nonsporeforming bacteria, spore-forming bacteria, actinomycetes, and fungi are in the order of $40-45 \%, 19-21 \%, 34-35 \%$, and less than $1 \%$, respectively.

It is now generally recognized by soil microbiologists that any conclusion on the microflora of a soil based on information obtained by isolation of bacteria, fungi, and actinomycetes on laboratory cultural media will be unsatisfactory. Direct observation of soil particles suggests major components of the soil microflora are not isolated on agar plates and the population will 
be underestimated by one to two orders of magnitude. In addition, it is now believed that a knowledge of bacterial genera within a soil will not contribute to an understanding of the function of the bacteria within the soil (after Ausmus and Witkamp 1974). A better approach may be to classify microorganisms into functional groups based on the substrates they utilize. The pioneering work done in this area was by Lochhead, who classified bacteria in terms of their vitamin and amino acid requirements, and Waksman, who used plant-derived substrates used by the microorganisms as a description.

An estimation of the microbial biomass may be useful. This has been achieved by dilution plating, direct observation of the soil particles (e.g., fluorescent antibody techniques and scanning electron microscopy), ATP determinations, measurement of soil respiration, and chemical techniques like analysis of chitin production by soil fungi (Gray and Williams 1971; Ausmus and Witkamp 1974). Recent work by Witkamp (1974) has shown ATP measurements to be an excellent measure of microbial biomass that can be directly correlated with soil respiration, substrate quality, and soil temperature but not total microbial numbers. It must be concluded that soil analyses based on the determination of bacterial numbers using plate count techniques are inadequate, as the numbers obtained will not be a satisfactory estimation of either bacterial biomass or activity.

Research on the microbiology of Appalachian strip-mine spoil undertaken by Wilson (1965) contributed toward the knowledge needed for the management of the revegetation of the spoil. As may be expected, the total number of bacteria, fungi, and actinomycetes was found to be markedly reduced in nonvegetated spoil compared to revegetated spoil and nearby undisturbed land in strip-mining areas in West Virginia and adjacent Pennsylvania. Wilson believed that the presence of vegetation exerted a greater influence upon the microflora of spoil than the low $\mathrm{pH}$ caused by sulphur-oxidizing bacteria. The nutritional requirements of the bacterial isolates were found by Wilson to be more complex for organisms obtained from vegetated spoil than nonvegetated spoil. The features of the bacterial population that developed after revegetation are the marked increase in physiological groups with ability to produce ammonia from proteins and amino acids, produce nitrate from ammonia, reduce nitrate, degrade cellulose, and produce polysaccharides. In general, the number of sulphur-oxidizing bacteria was reduced in the revegetated strip-mine spoil.

The ability of bacteria to produce polysaccharides undoubtedly aids soil aggregation. A recent review emphasized that intermolecular forces between polysaccharides of microbial origin and soil clays were largely responsible for soil aggregation (Finch et al. 1971). Soil aggregation is an important property and will ensure the access of air to plant roots, improve drainage, and prevent soil erosion. Wind erosion of spoil will be a potential problem. For example, soil aggregates less than 0.8 $\mathrm{mm}$ in diameter are moved by winds of about $30 \mathrm{mph}$ (Skidmore and Woodruff 1968). This means the fine-textured overburden generated by lignite surface mining and spent shale wastes will be subject to wind erosion if not revegetated.

During succession, plant residues are converted to humic material with carbon and nitrogen accumulating in the soil. Wilson (1965) reported the organic matter content in the nonvegetated and vegetated spoils and in the undisturbed soil as carbon $0.65,0.93$, and $2.32 \%$ and nitrogen $0.075,0.110$, and $0.245 \%$, respectively. Wilson concluded that the liming of the spoils, proper fertilization, and reseeding with forage crops and legumes will hasten the naturally slow build-up of organic matter and nitrogen accumulation in the spoil.

Another useful approach to the study of plant community successions is the measurement of soil enzyme activity during succession. Rice and his colleagues conducted investigations on the revegetation of infertile abandoned fields in central Oklahoma and southeastern Kansas. Four stages in the old-field succession can be recognized:

1) a pioneer weed stage (2-3 years),

2) an annual grass stage (9-13 years),

3) a perennial bunchgrass stage (40 years or more duration), and

4) the climax prairie.

The species of plants invading old fields is in the same order as their increasing nitrogen and phosphorus requirements namely, Coreopsis tinctoria, Aristida oligantha, and Andropogon scoparius. The activities of amylase, cellulase, and invertase were generally highest in the first successional stage and declined in the later stages. Seasonal maxima for the enzyme activity were pronounced in spring and summer. In contrast, urease and dehydrogenase activities increased during the succession. The enzyme activities were not correlated with either the $\mathrm{pH}$ or organic carbon content of the soil but appeared related to the type of vegetation and hence organic matter added to the soil during the succession (Pancholy and Rice 1973). In a more recent study on the factors preventing the revegetation of a denuded area adjacent to an abandoned zinc smelter, Rice and co-workers (Pancholy et al. 1975) found, as expected, that high concentrations of cadmium and zinc and low $\mathrm{pH}$ probably caused the area to remain bare. Comparisons between selected soil factors in the bare smelter site and a controlled site were made. As expected, the mean numbers of bacteria, fungi, and actinomycetes in the bare site were considerably lower than in the control soil. Urease and dehydrogenase activities proved to be an excellent indicator of microbial activity, with low activity in the bare soil and high activity in the control soil. Data were presented to show that total available nitrogen, ammonification, and nitrification were significatly reduced in the denuded plots. These studies suggest that the monitoring of soil enzyme activitics will indicate the plant growth potential of a soil and give insight into the microbial processes necessary for soil formation.

The development of ecosystem level models of the revegetated mining spoil would be useful in understanding the complexity of soil formation and plant succession. The effect of grazing, soil moisture, temperature, and added nitrogen and phosphorus on the primary productivity could be predicted. The usual approach is to construct a model with abiotic, producer, consumer, decomposer, and nutrient components and simulate the functioning of the ecosystem using a computer. This approach has been undertaken in the IBP Grassland and Tundra Biome studies (Burnell 1972; Van Dyne and Anway 1976).

A recent review of the global nitrogen cycle by Hardy and Holsten (1973) summarizes the mechanisms by which nitrogen could accumulate in mine spoil. Chemical transformation of nitrogen in the atmosphere to utilizable nitrogen are the ozonization of nitrogen and nitric oxide, the hydration of nitrogen dioxide, the oxidation of ammonia, and the lightningmediated oxidation of nitrogen. Rain will contain ammonium, nitrate, and nitrite ions and represents a major input of nitrogen compounds into soil. The quantity of nitrogen precipitated is of the order of $1-10 \mathrm{~kg}$ per hectare per year. There is a spring maxima in unpolluted areas and a winter maxima in polluted 
areas (Junge 1958). The combined nitrogen input from biological fixation and rain is believed to be sufficient to maintain rangeland productivity (Steyn and Delwiche 1970).

Nitrogen-fixing microorganisms can be classified as obligatory symbionts, associative symbionts, and asymbionts or free-living $\mathrm{N}$-fixers. The classic nitrogen-fixing symbiont is the genus Rhizobium that forms root nodules on leguminous plants, e.g., Rhizobium trifoli nodulates clover. A typical associative relationship based on a morphological involvement is the fungal and algal components in a lichen while free-living nitrogenfixing bacteria abound in the phyllosphere and rhizosphere of plants (Hardy and Holsten 1973). Recently cultural media were developed to cultivate Rhizobia and fix atmospheric nitrogen independent of legume tissue which means their assignment to obligatory symbionts may need reassessment.

The amount of nitrogen fixed in permanent grasslands was estimated to be $15 \mathrm{~kg}$ of $\mathrm{N}_{2}$ per hectare per year (Hardy and Holsten 1973). Recently more information has become available on rhizosphere associations such as the symbiotic association of Azotobacter paspali with the subtropical grass Paspalum natatum (Dobereiner et al. 1972). There is a high energy demand for nitrogen fixation. Elevated levels of exudation in tropical $\mathrm{C}_{4}$ plants compared to temperate $\mathrm{C}_{3}$ plants support larger numbers of nitrogen-fixing bacteria in the rhizosphere of tropical grasses (Dobereiner 1974).

Renewed interest in the field of associative nitrogen-fixing symbionts has led to the discovery of nitrogen fixation in staple food crops like rice, maize, and wheat. The effectiveness of applying free-living nitrogen-fixing bacteria to crops was recently tested (Smith et al. 1976). Plots of pearl millet and guinea grass were inoculated with Spirillum lipoferum and the yield of these grasses was significantly higher than untreated control plots. Smith and his co-workers claimed that the inoculation procedure produced yicld equivalent to the application of $42 \mathrm{~kg}$ of nitrogen per hectare. The cost and practicability of the application of this technique to agriculture should be investigated. The rising cost of natural gas used to produce nitrogen fertilizers may make a biological procedure more attractive.

Plant breeding and strain selection for grass-nitrogen-fixing bacteria associations would be worthwhile, and the effect of different nitrogen and phosphorus fertilization regimes on the nitrogen fixation should be investigated. A new approach to obtain nitrogen-fixing bacteria for the rhizosphere was suggested by Dixon and Postage (1972), who demonstrated the transference of the nitrogen-fixing (nif) gene from Klebsiella pneumoniae to $E$. coli. Brill (1974) believes that techniques developed in molecular biology may eventually have a practical application by incorporating nif genes into plant cells, enabling plants to directly obtain their nitrogen from molecular nitrogen.

It is important to remember that the largest pool of nitrogen in the soil is found in decaying plant and animal remains. Microorganisms are responsible for the release of ammonia from proteineous material. The proportion of nitrogen assimilated into microbial cells is high when the carbon:nitrogen ratio is high as would be found in mine spoil. Obviously the $\mathrm{C}: \mathrm{N}$ ratio of plant material used in mulching spoil can influence the nitrogen status of the spoil. If insufficient nitrogen is present in the plant material, nitrate and ammonium ions will be depleted by the microorganisms degrading the mulch and hence not available for plant growth (Gray and Williams 1971).

In soil material containing low phosphate levels, vesiculararbuscular mycorrhizas will be important in increasing the phosphate-absorbing surface of the roots of grasses and perennials. A practical role for these endo-mycorrhizas analogous to the uses of Rhizobium may be possible especially with the high cost of phosphorus fertilizers (Tinker 1975). An example of the benefit of inoculating perennials with mycorrhizal fungi was reported by Powell (1976), who infected white clover grown in New Zealand hill country soils in pot trials with an efficient phosphate-promoting mycorrhizal fungus of the genus Glomus. He found significant increases in dry matter production of white clover plant after infection with Glomus sp. over indigenous mycorrhizal fungi in a wide range of soils, suggesting field inoculation may be a feasible alternative to heavy application of superphospate.

A free-living heterotropic nitrogen-fixing bacterium, Azotobacter, may contribute to the nitrogen status of soils. Its activity may be most important in the rhizosphere of plants colonizing spoil with low nutrient levels. The association of Azotobacter with a sand dune plant Ammophila arenaria was reported by Hassouna and Wareing (1964). Factors that favor the growth of Azotobacter include high C:N ratios, low partial pressures of oxygen, a molybdenum supply, and neutral to alkaline soil reaction (Mulder and Brotonegoro 1974). These conditions are often met in the rhizosphere. The root excretions and buffering in the rhizosphere stimulate Azotobacter growth and nitrogen fixation. The possible role of Azotobacter in soil formation in mining spoils is undefined.

Symbiotic nitogen-fixing bacteria may have a role in soil formation in the mining spoils. In general, Rhizobium spp. that form nodules on legumes will multiply in the rhizosphere but are less well adapted to the soil. When a leguminous crop is introduced to an area, inoculation with the appropriate Rhizobium strain is usually necessary (Fahroeus and Junggren 1968). A recent investigation suggess the $\mathrm{N}$-fixing Rhizobium strains are able to survive and nodulate legumes in alkalinesaline soils comparable to spent shale wastes (Bhardway 1975).

A judicious choice of a nitrogen-fixing plant for seeding spoil will accelerate revegetation of the mining wastes. The classic example of the initial colonization of a bare site by nitrogenfixing plants was described by Crocker and Major (1955). The pioneer vegetation on spoil laid bare by a receding glacier was dominated by alder, a nonleguminous nitrogen-fixing tree, which increased the organic nitrogen content of the soil. Apparently the symbiont nodulating the alder (Alnus spp.) is an actinomycete, not a member of the genus Rhizobium.

The characteristic grassland plants in western North Dakota vary with the topography, soil texture, alkalinity carbonate content, and degree of disturbance of the soil (Hanson and Whitman 1938; Wright and Wright 1948). A climax grassland usually consists of the dominants blue grama (Bouteloua gracilis), needlegrass (Stipa comata), sedge (Carex filifolia), and prairie Junegrass (Koeleria cristata). Over-grazing leads to an abundance of sagebrush (Artemesia tridentata), while less favorable soil conditions lead to the growth of western wheatgrass (Agropyron smithii). The primary colonizer of eroded slopes is little bluestem (Andropogon scoparius), which is unpalatable to cattle. Also important in the initial colonization of bare soil in western states are nonleguminous forbs of the genera Ceanothus and Shepherdia that fix nitrogen. Although no species have been grown on artificial media, and Koch's postulates not fulfilled, the symbionts in these nonleguminous nodule-bearing plants have bcen grouped together as Frankia.

The successful functioning of the nitrogen cycle within mining wastes will be necessary for revegetation and soil 
formation. Ammonia released during the decomposition of plant residues is oxidized to nitrate by nitrifying bacteria or complexed by the humic material within the soil and conserved for plant growth. In alkaline spoil, the Nitrobacter group that is responsible for the oxidation nitrite to nitrate is suppressed by ammonium ions, and the volatilization of free ammonia from the spoil may be appreciable above $\mathrm{pH}$ 8.0. The salt intolerance of nitrifying bacteria is well known, while the presence of phosphate considerably increases the nitrifying activity (Alexander 1965; Finch et al. 1971; Skujins 1973).

Disturbed grassland and forest ecosystems are characterized by accelerated nitrifying activity (Rice and Pancholy 1973). Highly soluble nitrate ions not fixed by humic material and clay minerals are rapidly leached from the soil (Likens and Bormann 1972). Apparently the stimulation of organic matter decomposition and the disturbance of the soil reverses the inhibition of nitrification by plant derivatives like tannins (Rice and Pancholy 1973). Strip-mining activities in western North Dakota will involve overburden segregation. A danger of the conversion of exchangeable ammonium to nitrate-nitrogen in topsoil storage piles is a potential water pollution problem, while the nitrogen needed for plant growth may be lost through leaching. However, denitrification is a possible mechanism for the loss of nitrates in the disturbed topsoil and overburden during wet conditions. A good supply of readily oxidizable organic material, a high nitrate level, poor drainage, neutral or alkaline $\mathrm{pH}$, and summer temperatures are required for denitrification (Alexander 1965).

A possible reclamation procedure may be the application of sulphur to calcareous spoil. Sulphur-oxidizing bacteria, especially of the genus Thiobacillus, produce sulphuric acid from sulphur, which lowers the $\mathrm{pH}$ (McLaren 1973) and reacts with calcium carbonate to produce gypsum, which plays an important role in the conversion of sodium saturated clay to calcium clay. When the anionic sites on clays like montmorillonite are occupied by sodium ions, the clay has serious physical defects. It is likely to be difficult to till and exhibits high plasticity and poor water infiltration; but when wet it exhibits a high swelling capacity, and shrinkage when drying causes severe cracking. In the development of polders in the Netherlands, Thiobacillus thiooxidans oxidized sulphur derived from the sulphide in the sediments Zuider Zee to sulphuric acid, accelerating the production of agricultural soil (Schreven and Harmsen 1968). Generally the number of Thiobacilli in soil is low, but they rapidly increase in number when sulphur is added; e.g., Moser and Olson (1953) reported increases from 10 to $2 \times 10^{5}$ cells per gram of soil. It should be remembered that sodium ions displaced from clay by sulphuric acid will be readily leached from mine spoil and may contribute to the water pollution problem.

In conclusion, this review has discussed the adverse properties of spent shale wastes and overburden from surface mining in western states that will discourage soil formation and revegetation. Soil microorganisms have an important role in the reclamation of the spoils, especially in the creation of soil organic matter and the accumulation of sufficient nitrogen for plant growth. A more detailed knowledge of the microbial processes involved in soil formation and plant growth may suggest further strategies to be used to restore mined land.

\section{Literature Cited}

Anonymous. 1973. Processes, procedures and methods of control pollution from mining activities. U.S. Environ. Protection Agency-430/9-73-Oil. $390 \mathrm{p}$.
Alexander, M. 1965. Microbial ecology. John Wiley and Sons, New York. p. 424-429.

Ausmus, B. S., and M. Witkamp. 1974. Litter and soil microbial dynamics in a deciduous forest stand. Oak Ridge Nat. Lab. Rep. EDFB-IBP-73-10. p. 4-11.

Bhardway, K. K. R. 1975. Survival and symbiotic characteristics of Rhizobium in saline- alkali soil. Plant and Soil 43:377-385

Brill, W. J. 1974. Genetics of $\mathrm{N}_{2}$-fixing organisms. In: The Biology of Nitrogen Fixation, edited by A. Quispel, North-Holland Publ. Co., Amsterdam. p. 639-662.

Boyd, W. L., J. T. Staley, and J. W. Boyd. 1966. Ecology of soil microorganisms of Antartica. In: Antarctic Soils and Soil Forming Processes, edited by J. C. F. Tedrow. Nat. Acad. Sci., Nat. Res. Counc. p. 125-159.

Buckman, H. O., and N. C. Brady. 1960. The nature and properties of soils, 6th edition. Macmillan Company, New York. p. 567.

Buol, S. W., F. D. Hole, and R. J. McCracken. 1973. Soil genesis and classification. Iowa State Univ. Press. 360 p.

Burnell, F. 1972. Workshop on nutrient-flux and decomposition modeling faculty of forestry and institute of animal ecology. Univ. of British Columbia. p. 39.

Cook, C. W. 1976. Surface-mine rehabilitations in the American West. Environ. Conserv. 3:179-183.

Crocker, R. L., and J. Major. 1955. Soil development in relation to vegetation and surface age at Glacier Bay, Alaska. J. Ecol. 43:427-448.

Dobereiner, J. 1974. Bacteria in the Rhizosphere. In: The Biology of Nitrogen Fixation, edited by A. Quispel. North-Holland Publ. Co., Amsterdam. p. 86-120.

Dobereiner, J., J. M. Day, and P. J. Dart. 1972. Nitrogenase activity and oxygen sensitivity of the Paspalum nodatum-Azotobacter paspali association. J. Gen. Microbiol. 71:103-116.

Dixon, R. A., and J. R. Postgate. 1972. Genetic transfer of nitrogen fixation from Klebsiella pneumoniae to Escherichia coli. Nature 237:102-104.

Fahroeus, G., and H. L. Junggren. 1968. Pre-infection phases of the legume symbiosis. In: The Ecology of Soil Bacteria, edited by T. R. G. Gray and D. Parkinson. Liverpool Univ. Press. p. 396-421.

Finch, P., M. H. B. Hayes, and M. Stacey. 1971. The biochemistry of soil polysaccharides. In: Soil Biochemistry, Vol. 2, edited by A. D. McLaren and J. Skyjins. Marcel Dekker, New York. p. 258-319.

Fletcher, J. E., and W. P. Martin. 1948. Oscillatoria spp.: Appearance in biological crusts in desert soils following rain. Ecology 29:95-100.

Goodfellow, M., I. R. Hill, and T. R. G. Gray. 1968. Bacteria in a pine forest soil. In: The Ecology of Soil Bacteria, edited by T. R. G. Gray and D. Parkinson, Liverpool Univ. Press. p. 500-515

Gray, T. R. G., and S. T. Williams. 1971. Soil microorganisms. Longman, London. p. 240.

Grim, E. C., and R. D. Hill. 1974. Environmental protection in surface mining of coal. U.S. Environ. Protection Agency. 690/2-74-093.

Hanson, H. C., and W. Whitman. 1938. Characteristics of major grassland types in western North Dakota. Ecol. Monogr. 8:57-114.

Hassouna, M. G., and P. R. Wareing. 1964. Possible role of rhizosphere bacteria in the nitrogen nutrition of Ammophilia arenaria. Nature 202: 467-469.

Hardy, R. W. F., and R. D. Holsten. 1973. Global nitrogen cycling: pools, evolution, transformation, transfer, quantitation, and research needs. In: The Aquatic Environment, edited by J. Guarraia and R. K. Ballentine. USGPO. p. $87-134$.

Junge, C. E. 1958. The distribution of ammonia and nitrate in rainwater over the United States. Trans. Amer. Geophys. Union. 39:241-248.

Kilburn, P. O. 1973. Environmental analyses by a new energy-producing industry. Trans. 74th Nat. Meeting AICHE. p. 16.

Leisman, G. A. 1957. A vegetation and soil chronosequence on the Mesabi Iron Range spoil banks, Minnesota. Ecol. Monogr. 27:221-245.

Likens, G. E., and F. H. Bormann. 1972. Nutrient cycling in ecosystems. In: Ecosystem Structure and Function, edited by J. A. Wiens. Oregon State Univ. Press. p. 26-67.

McLean, A. D. 1973. Biochemistry and soil. Science 141:1141-1147.

Mishoustin, E. N. 1975. Microbial associations of soil types. Microbial Ecology 2:97-176.

Moser, V. S., and R. V. Olson. 1953. Sulphur oxidation in four soils as influenced by soil moisture and sulphur bacteria. Soil Sci. 76:251-257.

Mulder, E. G., and S. Brotonegoro. 1974. Free-living heterotrophic nitrogenfixing bacteria. In: The Biology of Nitrogen Fixation, edited by A. Quispel. North-Holland Publ. Co., Amsterdam. p. 37-85.

Omodt, H. W., F. W. Schroer, and D. D. Patterson. 1975. The properties of important agricultural soils as criteria for mines land reclamation. North Dakota Agr. Exp. Sta. Bull. 492. 52 p. 
Pancholy, S. K., and E. L. Rice. 1973. Soil enzymes in relation to old field succession: Amylase, cellulase, invertase, dehydrogenase and urease. Proc. Soil Sci. Soc. Amer. 37:47-50.

Pancholy, S. K., E. L. Rice, and J. A. Turner. 1975. Soil factors preventing revegetation of a denuded area near an abandoned zinc smelter in Oklahoma. J. Appl. Ecol. 12:337-342.

Powell, C. 1976. Mycorrhizal fungi stimulate clover growth in New Zealand hill country soils. Nature 264:436-438.

Rice, E. L., and S. K. Pancholy. 1973. Inhibition of nitrification by climax ecosystem. II. Additional evidence and possible role of tannins. Amer. J. Bot. 60:691-702.

Rice, E. L., and S. K. Pancholy. 1973. Inhibition of nitrification by climax ecosystem. Amer. J. Bot. 59:1033-40.

Rychert, R. C., and J. Skujins. 1975. Nitrogen fixation by blue-green algaelichen crusts in the Great Basin desert. J. Ecol. 53:768-773.

Sandoval, F. M., J. J. Bond, J. F. Power, and W. O. Willis. 1973. Lignite mine spoils in the Northern Great Plains-characteristics and potential for reclamation. In: Some Environmental Aspects of Strip Mining in North Dakota, Educ. Ser. 5, edited by M. K. Wali, North Dakota Geol. Surv., Grand Forks, N. Dak. p. 1-24.

Schmehl, W. R., and B. D. McCaslin. 1973. some properties of spent oil shale significant to plant growth. In: Ecology and Reclamation of Devastated Land, Vol. 1, edited by R. J. Hutnik and G. Davis. Gordon and Breach, London. p. 27-43.

Schreven, van D. A., and G. W. Harmsen. 1968. Soil bacteria in relation to the development of polders in the region of the former Zuider Zee. In: The Ecology of Soil Bacteria, edited by T. R. G. Gray and D. Parkinson. Liverpool Univ. Press. p. 474-499.

Sharabi, N. E., and D. Pramer. 1973. A spectrophotofluorometric method for studying algae in soil. In: Modern Methods in the Study of Microbial Ecology, edited by T. Rosswall. Swedish Nat. Sci. Res. Counc. p. 77-84.

Skidmore, E. L., and N. P. Woodruff. 1968. Wind erosion forces in the United States and their use in predicting soil loss. U.S. Dep. Agr. Handb. 346. p. 42.

Sujins, J. 1973. Dehydrogenase: An indicator of biological activities in arid soils. In: Modern Methods in the Study of Microbial Ecology, edited b T. Rosswall. Swedish Nat. Sci. Res. Counc. p. 235-243.

Smith, R. L., J. H. Bouton, S. C. Schank, K. H. Quesenherry, M. E. TyleI J. R. Milam, M. H. Gaskins, and R. C. Littell. 1976. Nitrogen fixation i grasses inoculated with Spirillum lipoferum. Science 194:1003-1005.

Stevens, P. R., and T. W. Walker. 1970. The chronosequence concept an soil formation. Quart. Rev. Biol. 45:33-350.

Steyn, P. L., and C. C. Delwiche. 1970. Nitrogen fixation by nonsymbionti microorganisms in some California soils. Environ. Sci. Tech. 4:1122-1128

Sushkina, N. N. 1970. Role of microorganisms in the primary process of so formation. Trans. 9th Intern. Congr. Soil Sci. IV. p. 663-672.

Tedrow, J. C. F., and F. C. Ugolini. 1966. Antarctic soils. In: Antarctic Soil and Soil-forming Processes, edited by J. C. F. Tedrow. Nat. Acad. Sci., Nal Res. Counc. p. 161-177.

Tinker, P. B. H. 1975. Effects of vesicular-arbuscular mycorrhizas on high plants. In: Symbiosis, edited by D. H. Jennings and D. L. Lee. Cambrid Univ. Press. p. 325-350.

Van Dyne, G. M., and J. C. Anway. 1976. A research program for and th process of building and testing grassland ecosystem models. J. Ran Manage. 29:114-122.

Ward, J. C., G. Moghiem, and G. O. G. Lof. 1971. Water pollution potenti of spent oil shale residues. 14030 EDB. 12/71. Environ. Protection Agenc: $116 \mathrm{p}$.

Weaver, G. D. 1975. Possible impacts of oil shale development on lar resources. J. Soil and Water Conserv. March-April 73-76.

Webley, D. M., D. J. Eastwood, and C. H. Giningham. 1952. Soil develo ment in sand-dunes. J. Ecol 40:168-178.

Wilson, H. A. 1965. The microbiology of strip-mine spoil. West Virginia Ag Sta. Bull. 506. 44 p.

Witkamp, M. 1971. Soils as components of ecosystems. Ann. Rev. Ecc System 2:85-110.

Wright, J. C., and E. A. Wright. 1948. Grassland types of south centr Montana. Ecology 29:449-460.
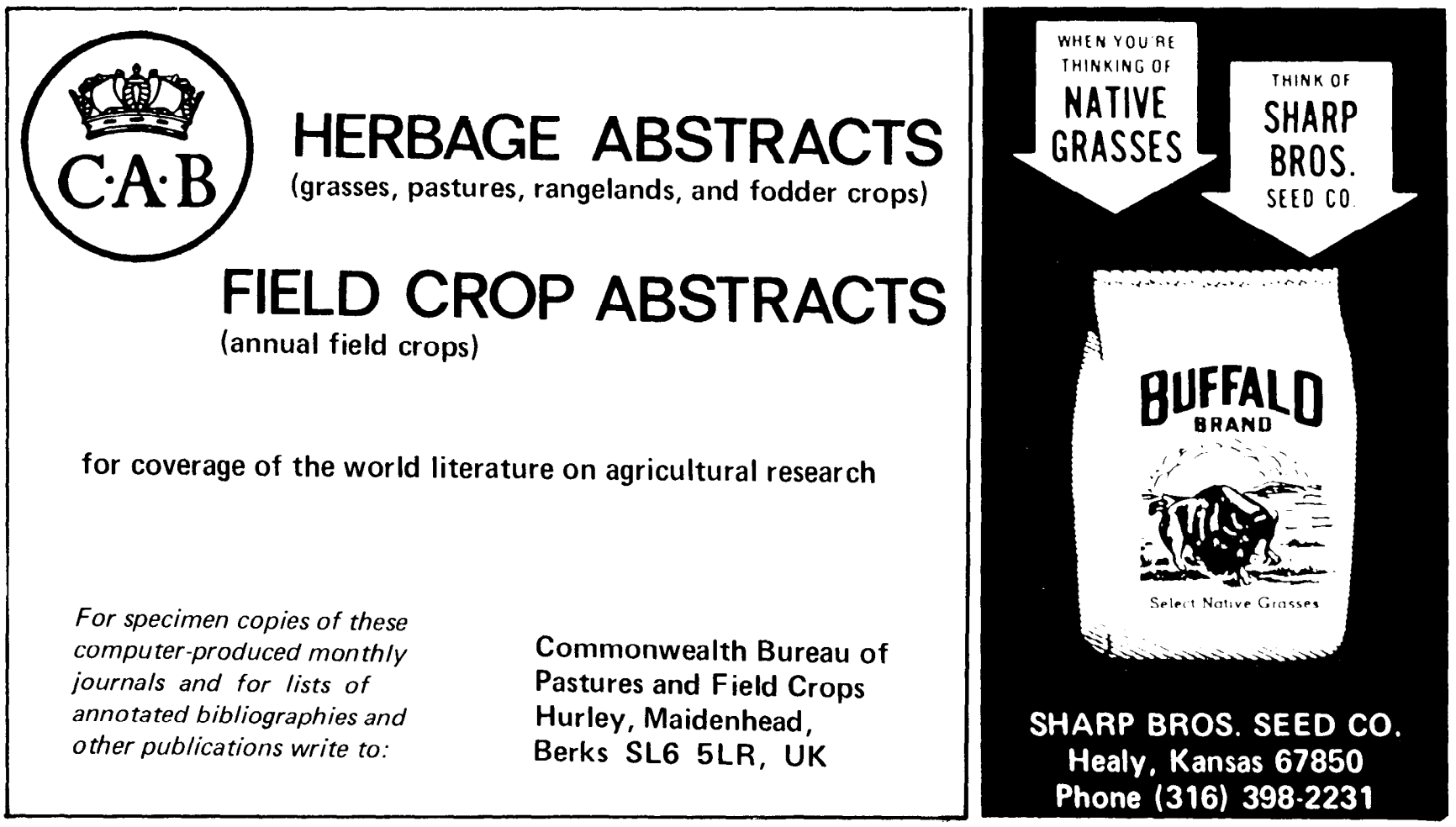